\title{
Improving Performance of the Evaporative Cooling System inside the Greenhouses and Its Effect on Tomato Productivity
}

\author{
Youssef, G.D.M. ${ }^{1}$, Yakout, T.R. ${ }^{1}$ and Doaa, M. Mostafa ${ }^{2}$
}

\begin{abstract}
An experimental study was conducted to determine the performance of two evaporative cooling systems, as well as the gradients of temperature and humidity along a greenhouse. The first system was the cooling unit, (CU) compared with the traditional fan-pad one, (F-P). The cooling unit was connected with two perforated ducts inside the greenhouse. The air temperatures and relative humidities on the longitudinal axis were measured outside and just after leaving the media and at each one meter from the pad media. They were also, measured in the traverse axis parallel to the pad media at distances $0.5,1.5$, 2.5 and $3.5 \mathrm{~m}$ from the edge of the greenhouse. A steady state mathematical model was modified to predict the greenhouse air temperature according to the state of the air just leaving the cooling media.
\end{abstract}

According to the experimental results, the non-uniform temperature changes were observed along the greenhouses for the two systems. The average temperatures of the $\mathbf{C U}$ greenhouse were 27.9, 30.4, 33.2, 29.1 and $27.9{ }^{\circ} \mathrm{C}$ for outside ambient temperatures of $28.7,32.4,35.4,32.1$ and $29.4^{\circ} \mathrm{C}$, respectively. The ranges of temperature gradient inside the $\mathrm{CU}$ greenhouse were $2.1,2.1,2.2,2.2$, and $2.1^{\circ} \mathrm{C}$. While in the F-P greenhouse, they were 5.9, 7.4, 8.2, 5.9 and $6.1{ }^{\circ} \mathrm{C}$ for the same ambient temperatures. The average air temperature entering to greenhouse was approximately 6.82 and $7.09{ }^{\circ} \mathrm{C}$ lower than the outside air temperature for $\mathrm{CU}$ and F-P systems. The greenhouse of CU system was higher in the relative humidity than F-P one. The average relative humidities were 69.0 and $61.8 \%$ for the $C U$ and F-P greenhouses, respectively, with increase percent $12.38 \%$. The averages $\mathrm{CU}$ efficiencies were $77.55 \%$ and $74.79 \%$ in the first and second days, respectively, while they were $72.97 \%$ and $70.19 \%$ for the same days for F-P system. Consequently, the $\mathrm{CU}$ system was averagely more efficient than the F-P system by $6.29 \%$ and $6.58 \%$. The water flow rate of the two systems to permit optimum wetness and air saturation were 5.6 and $6.5 \mathrm{~L} / \mathrm{min}$ for the $\mathrm{CU}$ and F-P evaporative cooling systems, respectively. The saving percentage in water circulation was $16.1 \%$ for the $\mathrm{CU}$ system. The total yield per plant was 6.24 and $5.48 \mathrm{~kg} /$ plant for the $\mathrm{CU}$ and F-P systems, respectively. The $\mathrm{CU}$ system increased the yield per plant with $13.82 \%$ over the F-P system.

Keywords: Greenhouses - evaporative cooling - FanPad system- cooling efficiency.

\footnotetext{
${ }^{1}$ Protected Cultivation Research Deprt., Horticultural Research Institute, A.R.C., Giza, Egypt

${ }^{2}$ Vegetable Research Deprt., Horticultural Research Institute

A.R.C., Giza, Egypt

Received March 1, 2015, Accepted March 25, 2015
}

\section{INTRODUCTION}

Reducing temperature is one of the main problems facing greenhouse management in hot climatic conditions. One of the most efficient approaches to reduce the difference between the inside and outside air temperatures is to improve ventilation system. Franco et al., (2014) stated that forced greenhouse crops are an ever more common means of cultivation worldwide. Current estimates put the surface area dedicated to such crops at 700,000 ha, 150,000 of which are located in the Mediterranean basin. Montero (2006) mentioned that the high spring-summer temperatures in the Mediterranean basin make evaporative cooling systems necessary. The evaporative cooling effect occurs as a result of the conversion of sensible heat into latent heat in mechanically supplied evaporated water. The tropical greenhouses require active evaporative cooling system such as pad-and-fan to ensure a suitable macroclimate for crop production. Excess heat causes indoor temperature to become hotter than desired resulting in detrimental effects to crop growth and production. The evaporative cooling of greenhouses is based on the evaporation of water in the mass of warm incoming air, thus allowing a decrease in temperature and increase in the humidity content of the air, (Kittas et al., 2003, Farmahini et al., 2012 and Jamaludin et al., 2014). This can be achieved by directly spraying water inside the greenhouse and combining it with natural ventilation (fog systems), or by obliging the incoming air to pass through dampened evaporative pads and installing fans to ventilate the greenhouse artificially (pad-fan cooling system), (Sethi and Sharma, 2007b and Jamaludin et al., 2014).

The main drawback of greenhouse evaporative cooling systems based on cooling pads and extracting fans is the thermal gradient developed along the direction of the airflow. High-temperature gradients of this type can markedly affect plant growth, and growers often combine cooling pads with shading, (Kittas, et al., 2003). The air saturation efficiency of the pad-fan system is greater than that of the fog system (Katsoulas et al., 2009); it is also cheaper (Sethi and Sharma, 2007a) and it consumes less water and energy (López et 
al., 2012). However, it requires extremely airtight greenhouse structures to ensure that all incoming air passes through the evaporative pads along part or the whole of the side wall, with powerful extractor fans being placed along the opposite wall to provide the required suction. All the energy terms that affect the energy balances for the greenhouse cover, plants, and soil were illustrated by Ibrahim, 1999, Youssef, 2007 and Ibrahim, 2010. A dynamic simulation model was adapted to predict air temperature and air relative humidity inside greenhouse diurnal variations of temperatures for greenhouse components such as glass cover, inside air, plant leaf, and top soil layer and their interactions were also studied.

The packing material is the key element in the heat and mass transfer process, as it fulfills two important functions: it provides a large contact surface for the mixing of the water and air flows, while at the same time ensuring that the transfer process takes as little time as possible. As a result, the amount of water evaporated increases and the temperature of the nonsaturated air decreases, (Franco et al., 2011). This material usually consists of a plastic grid, though it may also be composed of corrugated cellulose pads, vegetable fibers found locally (Gunhan et al., 2007, Ahmed et al., 2011 and Jain et al., 2011), such as wood chips, coconut fibre, etc., or porous inorganic material, (Gunhan et al., 2007) such as perlite, volcanic rock, etc. These materials are placed in such a way as to ensure that they present the maximum possible transfer surface and the minimum resistance to the passage of the airflow.

Franco et al., (2014) stated that an alternative to the use of the fog system in greenhouses would be the use of evaporative cooling boxes. This direct evaporative cooling technology is still evolving and incorporating a dehumidification system by means liquid desiccant to reduce the humidity of the ambient air and therefore achieve greater reduction in air temperature. This is essential in hot and humid climatic areas where the efficiency of these direct systems is low, (Farmahini et al., 2012). Franco et al., (2014) stated that evaporative cooling systems using a combination of evaporative pads and extractor fans require greenhouses to be airtight. They compared the performance of evaporative cooling boxes with four pads of different geometry and thickness manufactured by two different companies. The evaporative cooling boxes presented greater saturation efficiency at the same flow, namely $82.63 \%$, as opposed to an average figure of $65 \%$ for the cellulose pads; and also had a lower specific consumption of water, at around $3.05 \mathrm{~L} / \mathrm{h} . / \mathrm{m}^{2} \cdot /{ }^{\circ} \mathrm{C}$. Consequently, they conclude that evaporative cooling boxes are a good option for cooling non-airtight greenhouses. In Egypt,
Helmy et al., (2013) tested three pad materials namely; Se'd, Purdy and Samar with roof thin water film and found that the daily average cooling efficiencies of $88.4,83.1$ and $79.6 \%$ were obtained for Se'd, Purdy and Samar, respectively during testing days inside the combined system at $15 \mathrm{~cm}$ pad thickness and $0.45 \mathrm{~m} \mathrm{~s}-1$ pad face air velocity. Kittas et al., (2001) investigated the temperature and humidity gradients during summer in a commercial greenhouse producing cut roses, provided with a ventilated cooling-pad system and a half-shaded plastic roof. In a steady regime, the cooling process reached $80 \%$ efficiency and succeeded in maintaining greenhouse temperatures at $10^{\circ} \mathrm{C}$ lower than outside.

Jamaludin et al., (2014) found that temperature increased from evaporative pad area to exhaust fans area in a horizontal plane, while relative humidity showed an inverse pattern from temperature. In the vertical plane, temperature increased, while relative humidity decreased from lower level to the upper level. To predict the temperature gradients along a greenhouse, Kittas et al. (2003) proposed a climate model which incorporated the effect of ventilation rate, roof shading, and crop transpiration. The simulation indicated that high ventilation rates and shading contribute to reducing the temperature gradients. In order to maintain a suitable internal temperature, Attar et al., (2014) developed a thermal model to investigate the possibility to use the ground thermal energy for the greenhouse heating or cooling. Experiments in a greenhouse integrated with the ground heat storing system were conducted to evaluate the effectiveness of the control system. According to López et al., (2012) in a greenhouse equipped with evaporative pads a difference in temperature of up to $11.6^{\circ} \mathrm{C}$ was recorded with respect to a naturally ventilated greenhouse, whereas using the fog system this difference was 10.4 ${ }^{\circ} \mathrm{C}$. The main drawback of the pad-fan system was the horizontal temperature gradients, with a maximum difference of $11.4{ }^{\circ} \mathrm{C}$ between the pads and the fans. The fog system required higher energy consumption $(7.2-8.9 \mathrm{kWh})$ than the pad-fan system $(5.1 \mathrm{kWh})$ for continuous operations over one hour.

In Egypt, Abdel-Rahamn (2006) tested two greenhouses attached to a horizontal evaporative cooling pad, one with a long wheat straw and the other with an aspen fiber. The dimensions of each cooling pad were $1.22 \mathrm{~m}$ wide, $1.52 \mathrm{~m}$ high and $5.5 \mathrm{~m}$ long. He concluded that the air temperature reduction due to the evaporative cooling materials was ranged between 5 $10{ }^{\circ} \mathrm{C}$. The obtained results showed that the temperature differences caused by using the two cooling materials were $2-4{ }^{\circ} \mathrm{C}$. The cooling efficiencies were varied between (45-75\%) for both materials. Davies (2005) 
enhanced the cooling performance of an ordinary evaporative cooled greenhouse by means of regeneration of desiccation of the incoming air. The investigated system reduces the greenhouse temperature by $5^{\circ} \mathrm{C}$ as compared with the conventional evaporative system.

Jain (2007) developed an evaporative cooler named "two stages evaporative cooler" that reduces the wetbulb temperature of outside air before it passes through the evaporative cooling pads using a heat exchanger. Thus, more temperature drop is possible with the evaporative cooling system. In Egypt, Helmy et al., (2013) investigated two greenhouses that were cooled using fan-pad system. In addition, a thin water film was applied on the roof of one greenhouse to study the effect of roof water film and fan-pad (combined system) on the cooling performance. The two cooling systems were compared under the same condition.

The main purposes of this study were i) to investigate an alternative, economic and more effective evaporative cooling unit, ii) to evaluate its performance under different operating conditions, iii) compare its performance with the traditional fan-pad evaporative cooling system, iv) and evaluate their effects on crop productivity.

\section{MATERIALS AND METHODS}

Two identical mechanically ventilated gable-evenspan type greenhouses were utilized in summer season of 2011 at El-Sabahia Horticultural Research Station, Alexandria, at latitude $31.2^{\circ} \mathrm{N}$. Each greenhouse has gross dimensions of $8.0 \mathrm{~m}$ long, $4.0 \mathrm{~m}$ wide and $3.1 \mathrm{~m}$ high. One greenhouse was equipped with the traditional pad and fan evaporative cooling system as the control treatment, (F-P) as shown in Fig. (1a), while the other greenhouse was coupled with evaporative cooling unit, (proposed cooling system, CU) as shown in Fig., 1b). The cooling pad dimensions were $3.0 \times 0.6 \times 0.1 \mathrm{~m}$ with face area of $1.8 \mathrm{~m}^{2}$. One suction fan (single speed, direct driven, $60 \mathrm{~cm}$ diameter and $8000 \mathrm{~m}^{3} / \mathrm{h}$ discharge) was located on the leeward side of the greenhouse and the cooling pad on the opposite side toward the prevailing winds. It was supplied with $0.5 \mathrm{hp}$ water pump discharges $24(\mathrm{~L} / \mathrm{h})$ to circulate the water. On the other side the evaporative cooling unit as shown in Fig. (1a) has a square base with the dimensions of $1.20 \mathrm{x}$ $1.20 \mathrm{~m}$ and $0.80 \mathrm{~m}$ height. It has three opening from three sides, each $1.0 \times 0.6 \mathrm{~m}$ to hold the cellulose pad (three pieces each $1.0 \times 0.6 \times 0.1 \mathrm{~m}$ ). The three cellulose pads have a gross area of $1.8 \mathrm{~m}^{2}$ as the same area as the fan-pad system. The fourth side has three speeds extracting fan that connected with two square ducts $0.4 \times 0.4 \mathrm{~m}$ and 1.0 long which were isolated with foam, (Fig. 1c). They supply two 0.6 (m) diameter polyethylene ducts inside the greenhouse, with $0.05 \mathrm{~cm}$ holes, $0.40 \mathrm{~m}$ apart on two sides, (on 4 and 8 o'clock). This is shown in Fig. (1d). The two ducts were hanged across the longitudinal axis of the greenhouse above the plant canopy to uniformly distribute the cooled air through the greenhouse. The water distribution system was located above the cellulose pad opening, consisting of three channels, $1.0 \mathrm{~m}$ long and $0.10 \mathrm{~m}$ wide with 3 (mm) holes $50 \mathrm{~mm}$ apart. It was supplied with 0.5 (hp) water pump to circulate the water with a discharge rate of $24(\mathrm{~L} / \mathrm{min})$. There was a control valve to control the water flow rate over the cellulose pad. The basin of the evaporative unit has the dimensions of $1.20 \times 1.20 \mathrm{x}$ $0.10(\mathrm{~m})$ with a gross volume of 144 liters which was acted as water sump.

\section{Procedure and instrumentation}

The measurements were conducted from April to June 2011. Greenhouse temperatures were recorded at nine places in the longitudinal axis, $(0,1,2,3,4,5,6,7$ and $8 \mathrm{~m}$ ) from the cooling pad till the exhaust fan as shown in Fig. (2). The temperatures were also measured in the transverse direction parallel to the cooling pad at four places, $(0.5,1.5,2.5$ and $3.5 \mathrm{~m}$ from east to west). Solar radiation was recorded with the solarimeter pyranometer located above plant canopy inside the greenhouse. They readings were recorded every hour from 8 am to $6 \mathrm{pm}$. Other sensors were used to measure air temperature and relative humidity at the middle of the greenhouse using a thermograph, (type omega, C T $485 \mathrm{~B})$, and the air speeds using anemometer (EXTECH, Mini Thermo-Anemometer). The meteorological data from a meteorological station (5 KUE SKH 2013) were used to measure solar radiation flux incident on a horizontal surface (pyranometer), dry bulb air temperature (ventilated thermistor), wind speed and its direction (cup anemometer and wind vane), and the air relative humidity outside the greenhouses.

The tomato seedlings were raised in a tray with 200 growth blocks. The tomato variety (Lycopersicon esculentntum Miller.) V.T 916, indeterminate cv. was brought from a private company, (Techno. Green). The seedlings were vegetated out at the four leaves stage with an average length of $10.0 \mathrm{~cm}$. They were planted thereafter inside the greenhouses on the $2^{\text {nd }}$ of March, 2011. The planting arrangement was six rows and 12 plants per row. The field tests were conducted during the summer seasons of 2011 to investigate the effects of different macroclimatic conditions on fruit yield and fruit quality. The total soluble solids (T.S.S.) of the fruits were determined using a hand refractometer. Ascorbic acid and other pigments were estimated as described by A.O.A.C. (1990). 


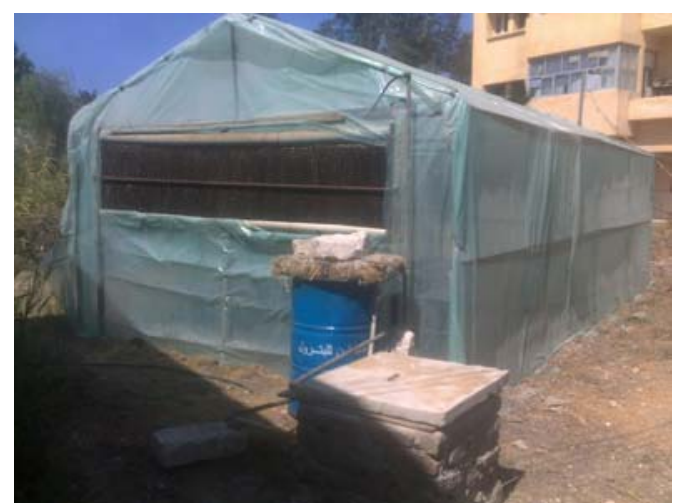

a- Traditional fan and cellulose pad

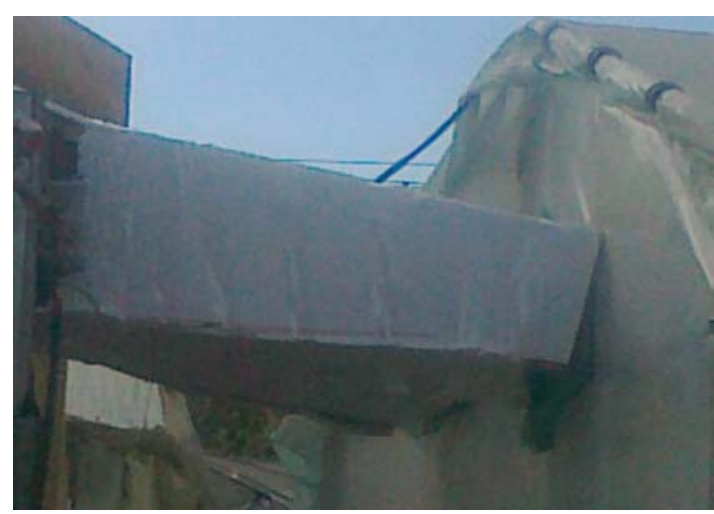

c- Two insulated ducts

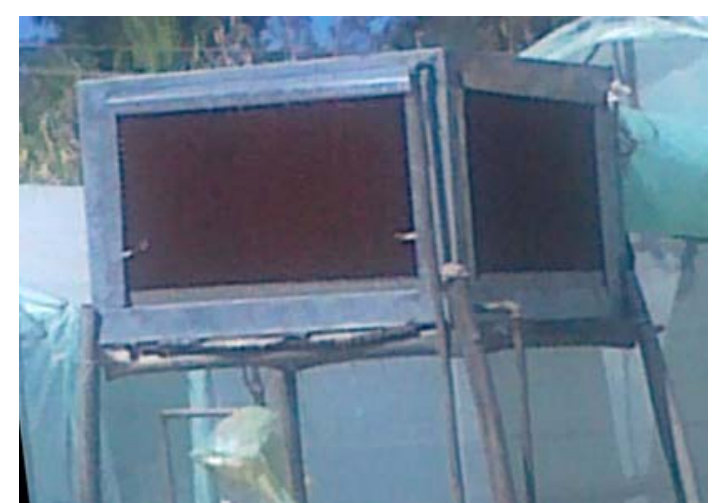

b- Proposed cooling unit

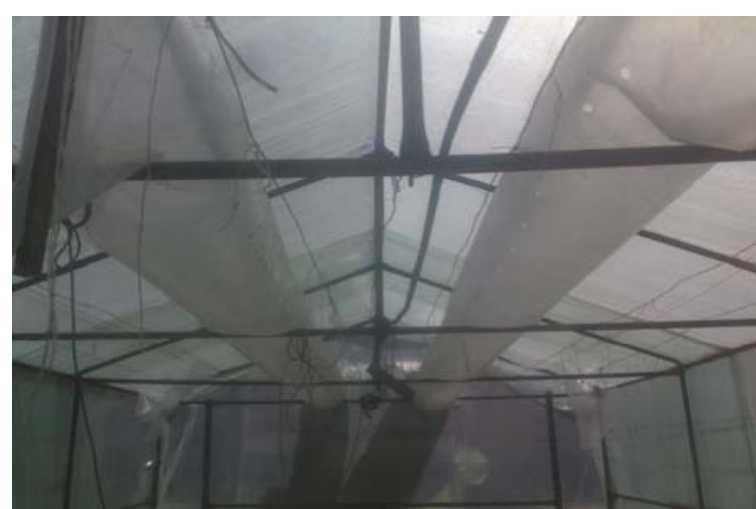

d- Two perforated polyethylene tubes

Fig. 1. The two evaporative cooling systems

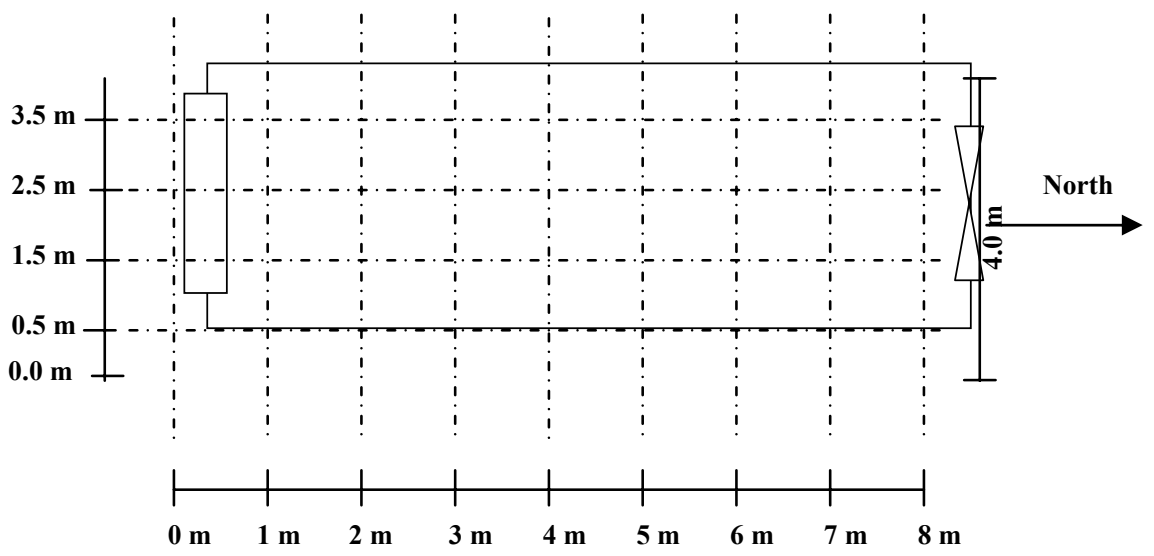

Fig. 2. A schematic diagram for sensors locations inside the greenhouse

\section{Mathematical model}

Steady state macroclimatic energy balance mentioned by Yakout (2007) and Ibrahim (2010) was modified to predict the ambient air temperature inside the greenhouse as affected by the evaporative cooling system. The general equation of the model was presented as follows (Hellickson and Walker, 1983; and Aldrich and Bartok, 1989):-

$\mathbf{Q}_{\mathrm{I}}= \pm\left(\mathbf{Q}_{\mathrm{cd}}+\mathbf{Q}_{\mathrm{g}}\right)+\mathbf{Q}_{\mathrm{v}}+\mathbf{Q}_{\mathrm{r}}$ 
Where:

$\mathrm{Q}_{\mathrm{I}}=$ solar energy available inside the greenhouse

$\mathrm{Q}_{\mathrm{cd}}=$ heat energy exchanged by conduction through greenhouse walls

$\mathrm{Q}_{\mathrm{g}}=$ heat energy losses (or gained) from (or to) the greenhouse floor

$\mathbf{Q}_{\mathbf{v}}=\mathbf{Q}_{\mathrm{vs}}+\mathbf{Q}_{\mathrm{vl}}$

$\mathrm{Q}_{v s}=$ sensible heat energy losses by ventilation,

$\mathrm{Q}_{\mathrm{vl}}=$ latent heat energy consumed in evapotranspiration process

$\mathrm{Q}_{\mathrm{r}}=$ heat energy losses by thermal radiation

The solar energy available $\left(\mathrm{Q}_{\mathrm{I}}\right)$ inside the greenhouse can be computed by the following formula:$\mathbf{Q}_{\mathbf{I}}=\tau_{\mathrm{c}}\left(\mathbf{A}_{\mathrm{f}}\right) \mathbf{S R}$

Where:

$\mathrm{SR}=$ solar radiation incident outside the greenhouse, $\mathrm{W} / \mathrm{m}^{2}$

$\tau_{\mathrm{c}}=$ greenhouse cover transmissivity for shortwave, decimal

$\mathrm{A}_{\mathrm{f}}=$ floor area of the greenhouse, $\mathrm{m}^{2}$

The solar energy absorbed by the floor can be computed as follows:

$\mathbf{Q}_{\mathrm{g}}=\tau_{\mathrm{c}}\left(\alpha_{\mathrm{g}}\right)\left(\mathbf{A}_{\mathrm{b}}\right)(\mathbf{S R})$

Where:

$\alpha_{\mathrm{g}}=$ absorptivity of the floor, (concrete).

$\mathrm{A}_{\mathrm{b}}=$ bare area of the greenhouse floor, $\mathrm{m}^{2}$

The heat energy losses by conduction $\left(\mathrm{Q}_{c d}\right)$ can be estimated as follows:-

$\mathbf{Q}_{\mathrm{cd}}=\mathbf{U}\left(\mathbf{A}_{\mathrm{s}}\right)\left(\mathbf{T}_{\mathrm{gr}}-\mathbf{T}_{\mathbf{o}}\right)$

Where :-

$\mathrm{U}=$ overall heat transfer coefficient, $\mathrm{W} / \mathrm{m}^{2} /{ }^{\circ} \mathrm{K}$.

$\mathrm{A}_{\mathrm{s}}=$ total surface area of the greenhouse cover, $\mathrm{m}^{2}$

$\mathrm{T}_{\mathrm{gr}}=$ greenhouse inside air temperature, ${ }^{\circ} \mathrm{C}$

$\mathrm{T}_{\mathrm{o}}=$ greenhouse outside air temperature, ${ }^{\circ} \mathrm{C}$

The sensible heat energy loss by forced ventilation $\left(\mathrm{Q}_{\mathrm{vs}}\right)$ can be computed as follows:-

$\mathbf{Q}_{v s}=\operatorname{ACR}(\mathrm{V} / \mathrm{v})\left(\mathbf{C}_{\mathrm{p}}\right)\left(\mathbf{T}_{\mathrm{gr}}-\mathbf{T}_{\text {evp }}\right)$

Where :-

$\mathrm{ACR}=$ air change rate, $\min ^{-1}$

$\mathrm{V}=$ greenhouse volume, $\mathrm{m}^{3}$

$v \quad=$ air specific volume, $\mathrm{m}^{3} / \mathrm{kg}_{\mathrm{a}}$

$\mathrm{C}_{\mathrm{p}}=$ specific heat of air, $\mathrm{J} / \mathrm{k}_{\mathrm{g}} \cdot{ }^{\circ} \mathrm{K}$

$\mathrm{T}_{\text {evp }}=$ air temperature just leaving the evaporative cooling, ${ }^{\circ} \mathrm{C}$
The latent heat energy consumed by evapotranspiration $\left(\mathrm{Q}_{\mathrm{vl}}\right)$ can be determined as follows:-

$\mathbf{Q}_{\mathrm{vl}}=\mathbf{E}(\mathbf{F})\left(\mathbf{Q}_{\mathrm{I}}\right)$

Where:

$\mathrm{E}=$ the ratio of evapotranspiration to solar radiation, decimal.

$\mathrm{F}=\mathrm{a}$ portion of the floor surface area covered by plants to the total floor area

The heat energy loss by thermal radiation $\left(\mathrm{Q}_{\mathrm{r}}\right)$ can be calculated by the following equation:-

$Q_{r}=\varepsilon_{s}\left(\tau_{t}\right)(\sigma)\left(A_{f}\right)\left(T^{4}{ }_{g r}-\varepsilon_{a} T^{4}{ }_{0}\right)$

Where:-

$\varepsilon_{\mathrm{s}}=$ emittance factor of the internal surfaces, decimal

$\tau_{\mathrm{t}}=$ transmissivity of cover for long wave radiation, decimal

$\sigma=$ Stefen-Boltezman constant, $5.67 \times 10^{-8} \mathrm{~W} / \mathrm{m}^{2} /{ }^{\circ} \mathrm{K}^{4}$

$\varepsilon_{\mathrm{a}}=$ emittance factor for outside atmosphere, decimal

The steady state energy balance on the greenhouse macroclimate rearranged to be in the following equation:

$\mathrm{SR}=\mathrm{C}_{1}\left(\mathrm{~T}_{\mathrm{gr}}-\mathrm{T}_{\mathrm{o}}\right)+\mathrm{C}_{2}\left(\mathrm{~T}_{\mathrm{gr}}-\mathrm{T}_{\mathrm{evp}}\right)+\mathrm{C}_{3}\left(\mathrm{~T}_{\mathrm{gr}}{ }^{4}-\varepsilon_{\mathrm{a}} \mathrm{T}_{\mathrm{o}}{ }^{4}\right)$

Unfortunately, the greenhouse temperature in equation (8) has different powers, whereas the direct solution is not an option. The try and error numerical technique was accomplished by assuming temperature values and calculating the value of solar radiation (SR). The value of the greenhouse temperature is acceptable if the error between the calculated and actual solar radiation in the range of an acceptable error. The mathematical mode was coded in a computer program to predict the greenhouse air temperature using FORTRAN language.

The evaporative cooling system efficiency is normally defined as follows (ASHRAE, 2005):-

$\eta_{\mathrm{ec}}=\frac{T_{o d b}-T_{e v p}}{T_{o d b}-T_{o w b}} \times 100$

Where:-

$\mathrm{T}_{\text {odb }}=$ dry bulb temperature of outside air just before entering the cooling pads, ${ }^{\circ} \mathrm{C}$

$\mathrm{T}_{\text {evp }}=$ dry bulb temperature of inside air just after leaving the cooling pads, ${ }^{\circ} \mathrm{C}$

$\mathrm{T}_{\text {owb }}=$ wet bulb temperature of outside air, ${ }^{\circ} \mathrm{C}$ 


\section{RESULTS AND DISCUSSION}

The solar radiation, air temperature and relative humidity through two consecutive days (25 and 26 May, 2011) are illustrated in Fig. (3a and b). The solar energy incident indicated that the maximum solar intensity is roughly $1000 \mathrm{~W} / \mathrm{m}^{2}$ around noon. It was varied from both days to another and through the day. Fig (3b) illustrates the distribution of the ambient air temperature and relative humidity through the same two days. It is clear that the increase of air temperature is directly proportional with the solar incident. The air temperature started to increase from sunshine till its maximum value at and around noon time as well as the solar radiation, and then declined till sunset. On the other hand, the behavior of the relative humidity is acting inversely with both the solar radiation and air temperature.

For a typical day, the outside weather conditions and temperatures at the middle of the cooling unit cooled (CU) and Fan and Pad (F-P) greenhouses were illustrated in both Fig. (4) and Table (1). The solar radiation incident reached $1061 \mathrm{~W} / \mathrm{m}^{2}$ as the maximum value and appeared so high. The ambient air temperature also, reached $33.3 \mathrm{C}$. The cooling unit (CU) showed a little decrease in the temperature just leaving the cooling media while, the maximum temperatures inside the CU and F-P greenhouses were 34.2 and 32.3 at 1:00 pm, respectively. The percentage increase for F$\mathrm{P}$ greenhouse than $\mathrm{CU}$ one was $5.64 \%$ and was achieved at 2:00 pm. The results in table (1) indicated that the means of cooling effect $\left(\mathrm{T}_{\mathrm{odb}}-\mathrm{T}_{\mathrm{evp}}\right)$ were 6.82 and 7.09 C for F-P and CU systems, respectively.

The distribution of the temperature inside the two greenhouses as affected by the two evaporating cooling system, (CU and F-P) is shown in Fig. (5) and Fig. (6). The temperature distribution in the longitudinal direction of the greenhouse outside and inside the greenhouse on distances $0,1,2,3,4,5,6,7$ and $8 \mathrm{~m}$ of the cooling side was demonstrated in Fig. (5).

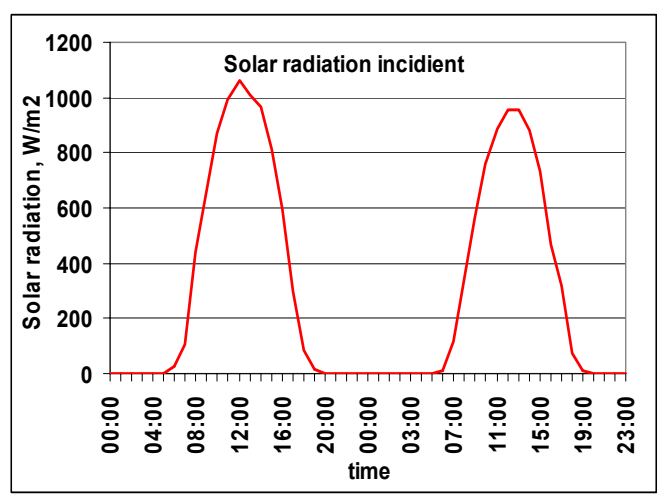

a- Solar radiation

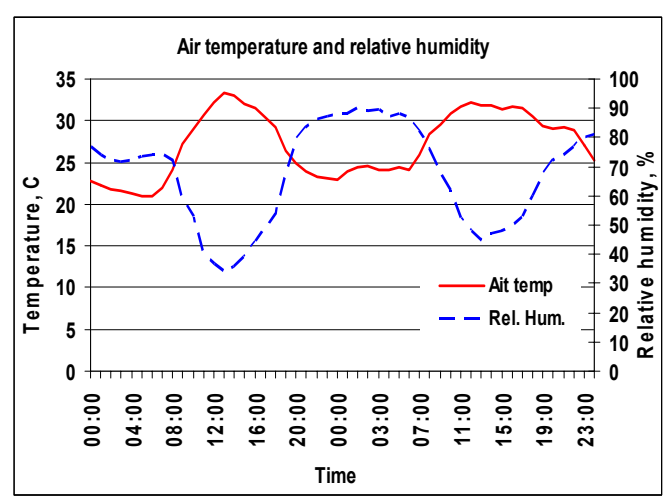

b- air temperature and relative humidity

\section{Fig. 3. Distribution of solar radiation, air temperature and relative humidity through two consequent days in the summer of Egypt}

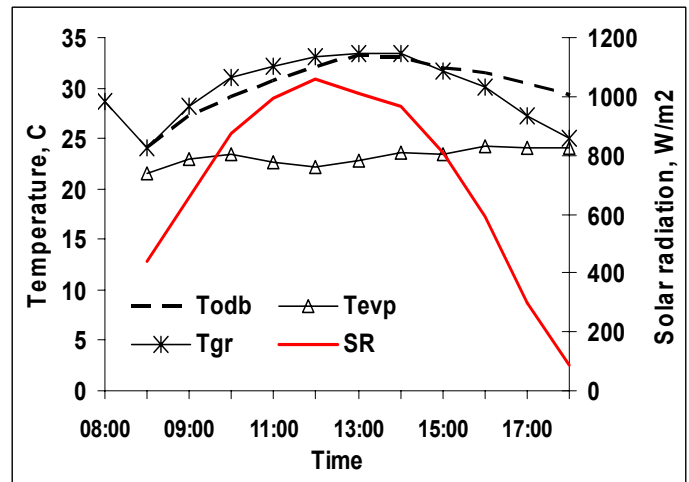

a- CU evaporative system

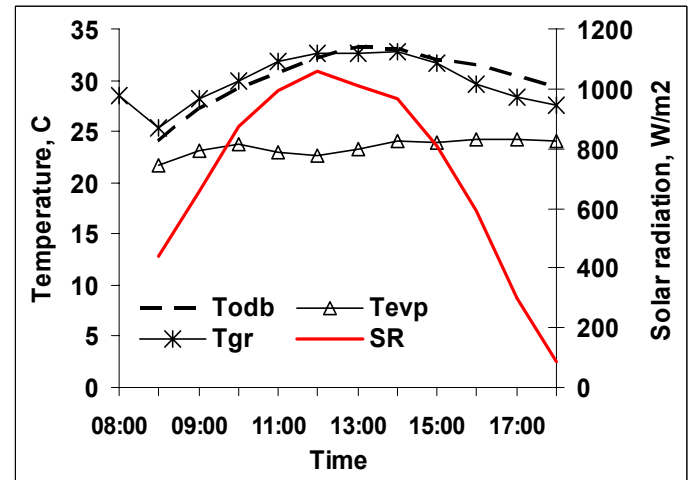

b- F-P evaporative system 
Fig. 4. Effect of the weather conditions on the two greenhouse temperatures Table1. The effect of the outside weather conditions on the two evaporative cooling systems performance on day 25-5-2011

\begin{tabular}{|c|c|c|c|c|c|c|c|c|c|}
\hline & \multirow[b]{2}{*}{ SR } & \multirow[b]{2}{*}{$\mathbf{T}_{\text {odb }}$} & \multirow[b]{2}{*}{$\mathrm{RH}_{\mathbf{0}} \%$} & \multicolumn{2}{|c|}{$\mathbf{T}_{\text {evp }}$} & \multicolumn{2}{|c|}{$\mathbf{T}_{\mathrm{gr}}$} & \multicolumn{2}{|c|}{$\mathbf{T}_{\mathrm{odb}}-\mathbf{T}_{\mathrm{evp}}$} \\
\hline & & & & F-P & $\mathrm{CU}$ & F-P & $\mathbf{C U}$ & F-P & $\mathbf{C U}$ \\
\hline 08:00 & & & & & & 28.50 & 28.7 & & \\
\hline $08: 15$ & 442 & 24.1 & 72.0 & 21.7 & 21.6 & 24.48 & 24.9 & 2.4 & 2.5 \\
\hline 09:00 & 658 & 27.3 & 59.0 & 23.1 & 22.9 & 28.91 & 27.8 & 4.2 & 4.4 \\
\hline $10: 00$ & 872 & 29.1 & 53.0 & 23.8 & 23.5 & 31.95 & 29.7 & 5.3 & 5.6 \\
\hline 11:00 & 994 & 30.7 & 40.0 & 22.9 & 22.6 & 32.77 & 31.8 & 7.8 & 8.1 \\
\hline $12: 00$ & 1061 & 32.2 & 32.5 & 22.7 & 22.2 & 33.81 & 32.1 & 9.5 & 10 \\
\hline 13:00 & 1011 & 33.3 & 32.0 & 23.3 & 22.8 & 34.2 & 32.3 & 10.0 & 10.5 \\
\hline $14: 00$ & 964 & 33.1 & 36.0 & 24.1 & 23.6 & 33.69 & 32.6 & 9.0 & 9.5 \\
\hline $15: 00$ & 811 & 32.0 & 39.1 & 23.9 & 23.5 & 31.92 & 30.7 & 8.1 & 8.5 \\
\hline 16:00 & 594 & 31.5 & 44.4 & 24.3 & 24.2 & 30.71 & 29.1 & 7.2 & 7.3 \\
\hline $17: 00$ & 300 & 30.4 & 49.0 & 24.2 & 24.1 & 28.35 & 28.2 & 6.2 & 6.3 \\
\hline $18: 00$ & 86 & 29.3 & 54.0 & 24.1 & 24.0 & 26.7 & 26.4 & 2.4 & 2.5 \\
\hline Mean & & & & 23.5 & 23.2 & 30.68 & 29.60 & 6.82 & 7.09 \\
\hline
\end{tabular}

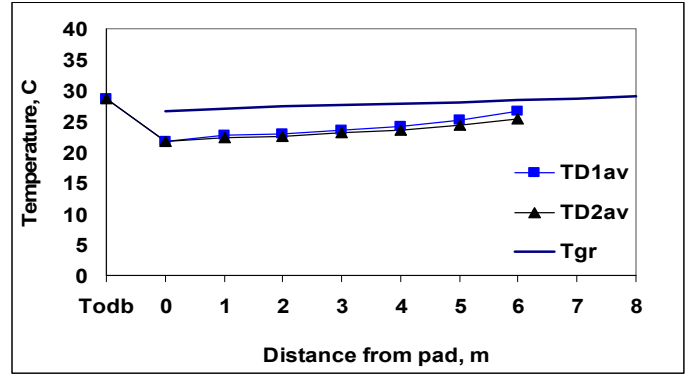

-a- 10:00 AM

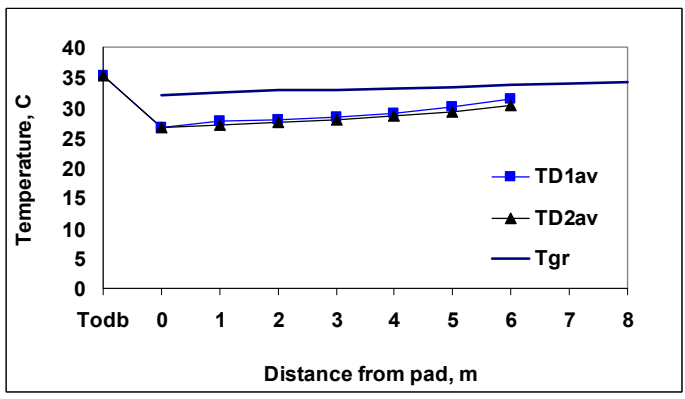

c- at noon

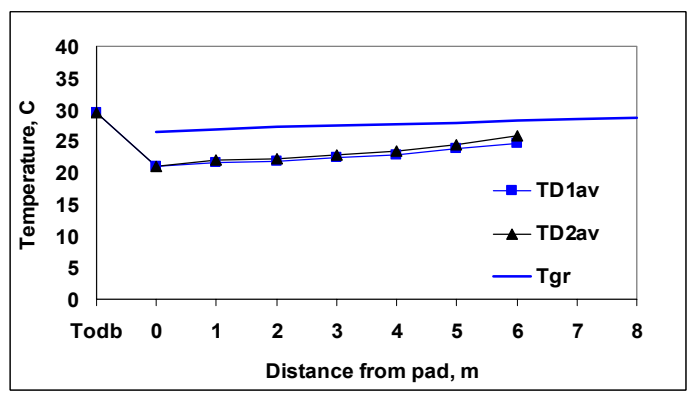

e- 2:00 PM

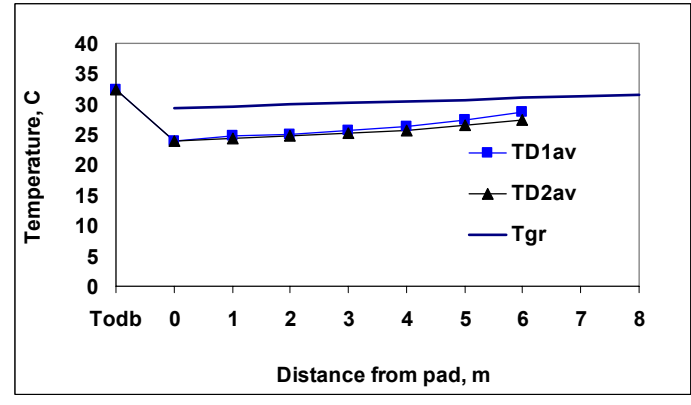

b- 11:00 AM

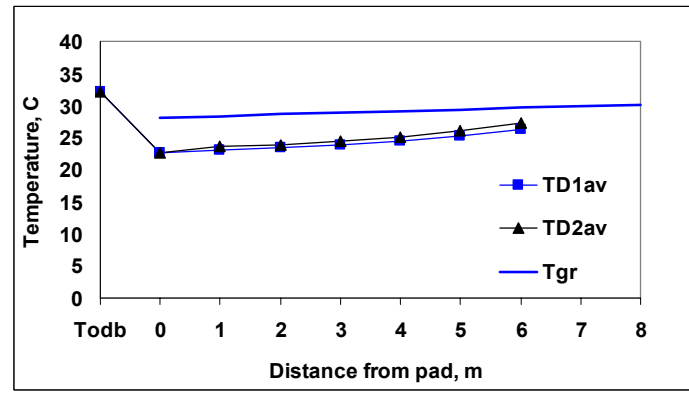

$\mathrm{d}-1: 00 \mathrm{PM}$

$\mathrm{TD} 1_{\mathrm{av}}=$ average eastern duct temperature

$\mathrm{TD} 2_{\mathrm{av}}=$ average western duct temperature

$\mathrm{T}_{\mathrm{gr}}=$ temperature for the center of greenhouse 


\section{Fig. 5. The longitudinal temperatures distribution outside and inside the $\mathrm{CU}$ cooled greenhouse at and around noon}

Figure (5) showed the cooling effect which indicated by the sudden drop of the temperatures after leaving the cooling media, while the ambient air temperature reached $33.3{ }^{\circ} \mathrm{C}$ at noon. The figure also, showed the temperatures gradient along the longitudinal axis of the greenhouse. The temperatures of the CU greenhouse were varied from 26.9-29.0, 29.4-31.5, $32.0-34.2,28.0-30.2$ and $26.5-28.6{ }^{\circ} \mathrm{C}$ with an average of $27.9,30.4,33.2,29.1$ and $27.9^{\circ} \mathrm{C}$ for outside ambient temperatures of $28.7,32.4,35.4,32.1$ and $29.4{ }^{\circ} \mathrm{C}$, respectively. The ranges of temperature gradient inside the CU greenhouse were 2.1, 2.1, 2.2, 2.2, and $2.1{ }^{\circ} \mathrm{C}$.

While in the F-P greenhouse, they were 5.9, 7.4, 8.2, 5.9 and $6.1{ }^{\circ} \mathrm{C}$ for the same ambient temperatures as shown in Fig. (6). The figure cleared out the high temperatures at the end of the greenhouse (Fan side) as it reached $35.3{ }^{\circ} \mathrm{C}$. These variations in the temperature gradient between the two systems would be attributed to the uniformly distributed cooled air of the two ducts inside the CU greenhouse. The F-P greenhouse was also, not so tight to permit good ventilation by extracting all the extra heat inside the greenhouse.
Hence the needs for the cooling unit as our greenhouses not well tight as mentioned by Franco et al., (2014). The CU system could be doubled or the face area of the media could be increased to achieve the desired cooling capacity. On contrary, increasing the face area of fanpad system could not be achieved because of the limited area of pad side of the greenhouse.

The temperature gradient in the transverse direction of the greenhouse just after leaving the cooling media was indicated in Table (2) and Fig. (7). The average temperature of the first half of the greenhouse, (facing east) showed little increase in the morning till noon than that of the second one, (facing west) then vise verse occurred on the after noon as the sun decline to sunset.

The two cooling system showed a little difference in the temperature just leaving the cooling media. The non-significant result was due to the same pad area and same cellulose pad materials were utilized in the two evaporative systems. But the goal that achieved was the good distribution of the greenhouse temperature inside the CU greenhouse.

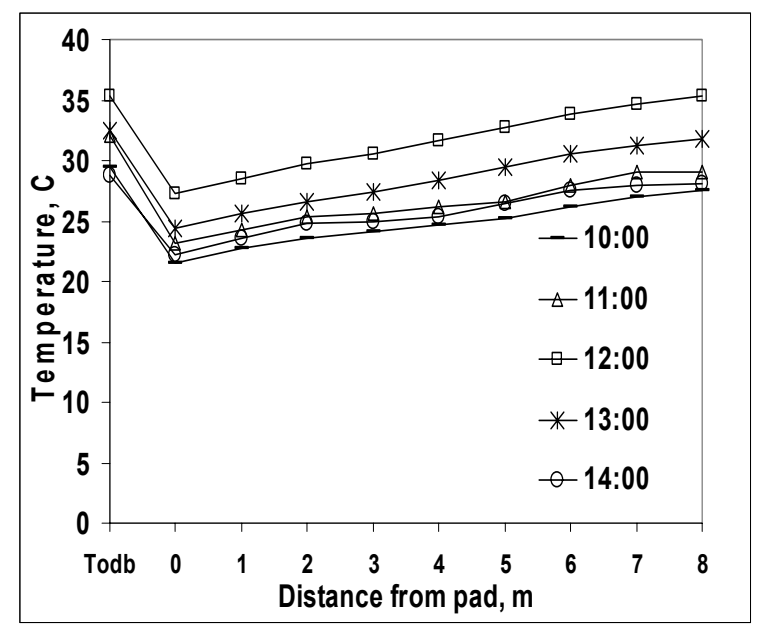

Fig. 6. The longitudinal temperatures distribution outside and inside the evaporative F-P cooled greenhouse at and around noon

Table 2. The temperature gradient in the transverse direction of the greenhouse

\begin{tabular}{lccccccc}
\hline & $\mathbf{0 . 5} \mathbf{~ m}$ & $\mathbf{1 . 5} \mathbf{~}$ & $\mathbf{2 . 5} \mathbf{~}$ & $\mathbf{3 . 5} \mathbf{~ m}$ & $\mathbf{T}_{\mathbf{o d b}}$ & $\mathbf{T}_{\mathbf{g r}}{ }^{*}$ & $\mathbf{T D}_{\mathbf{a v}}{ }^{* *}$ \\
\hline 10:00AM & 24.6 & 24.1 & 23.8 & 24.5 & 30 & 28.4 & 24.25 \\
\hline 11:00AM & 26.3 & 25.9 & 25.3 & 26.2 & 31.8 & 29.9 & 25.93 \\
\hline 12:00PM & 24.4 & 23.7 & 23.9 & 24.8 & 32.4 & 30.4 & 24.20 \\
\hline 1:00PM & 25.8 & 25.4 & 26.1 & 26.8 & 34.2 & 31.8 & 26.03 \\
\hline 2:00PM & 25.7 & 24.6 & 25.3 & 25.9 & 32.6 & 30.7 & 25.38 \\
\hline 3:00PM & 23.8 & 23.3 & 23.8 & 24.1 & 30.4 & 28.1 & 23.75 \\
\hline
\end{tabular}


* $\mathrm{T}_{\mathrm{gr}}=$ the average greenhouse temperatures, $\quad \mathrm{T}_{\mathrm{odb}}=$ outside ambient temperatures

$* *$ TDav $=$ average ducts temperatures

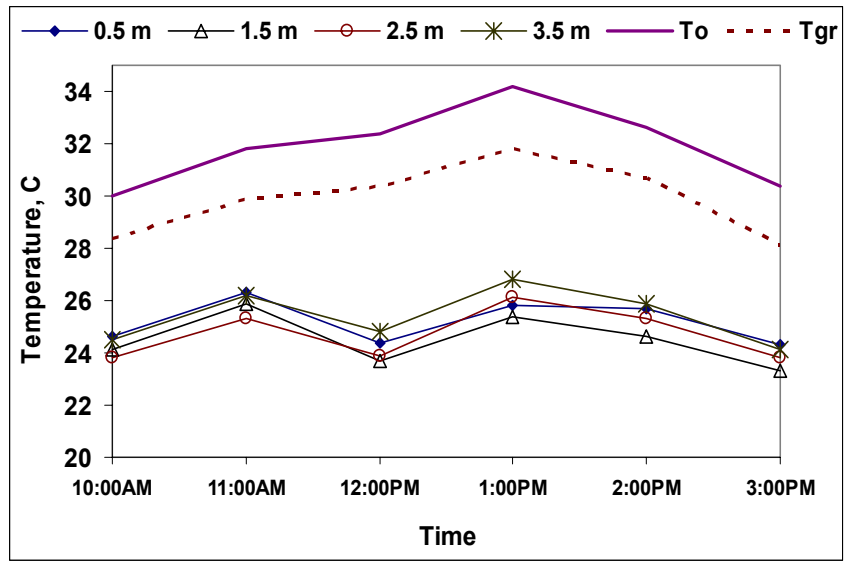

Fig. 7. The transverse temperatures profile outside, after leaving cooling media and center of the greenhouse of the $\mathrm{CU}$ evaporative system

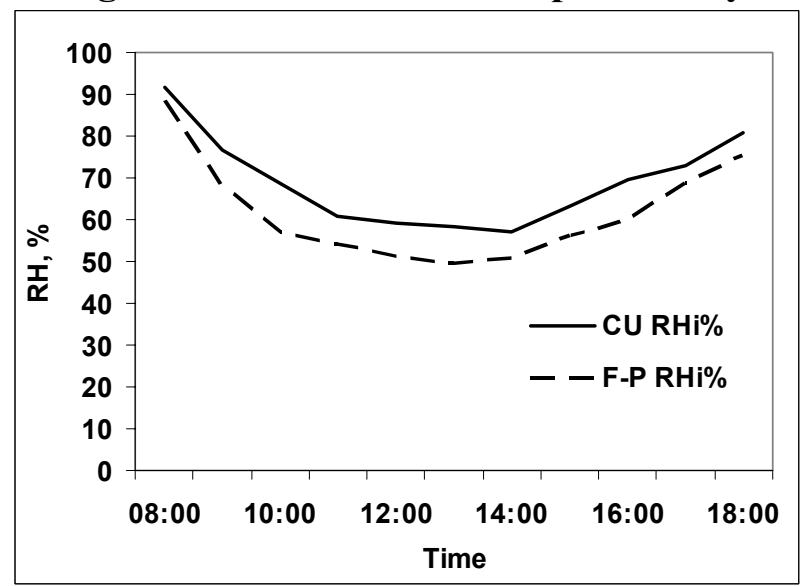

Fig. 8. Effect of the evaporative cooling systems on the relative humidities inside the two greenhouses

The drop in temperature in the evaporative cooling process depends on how much humidity the air can absorb i.e. a function of the air relative humidity. Relative humidity is the ratio between actual vapor pressure and the vapor pressure of water in air if the air is saturated at the same temperature. As a results, the efficiency of the evaporative cooling process is strongly depended on the outside ambient relative humidity or we can say the difference between the air dry bulb and wet bulb temperature. The evaporative cooling process is an adiabatic process i.e. at constant enthalpy as mentioned by Ibrahim, (2010). Psychometric tools version 2.1 was utilized to estimate the cooling efficiency of the two cooling systems as show in Fig. (9). Point (a) represents the state of outside ambient temperature, point (b) represents the state of temperature of air after it just leaving the cooling media and point (c) represents the virtual state of the air if it was saturated.

The performances of the two cooling systems were plotted on two different days as illustrated in Fig (10). The figure showed that the lower day relative humidities, the greater systems performance, i.e. the day of lower relative humidities was the lower air temperatures just leaving the cooling media and vise versa.

Effect of the outside relative humidity on the efficiencies of the two systems was showed in Fig. (11). The CU system achieved greater efficiencies than that of the F-P system. The CU efficiencies were ranged from 68.29 to $82.55 \%$ with an average of $77.55 \%$ and they were from 66.40 to $79.55 \%$ with an average of $74.79 \%$ in the first and second days, respectively. Whereas they were from 64.94 to $78.33 \%$ with an average of $72.97 \%$ and they were from 61.75 to $75.40 \%$ 
with an average of $70.19 \%$ for the F-P system on the same days. Consequently, the $\mathrm{CU}$ system was on the average more efficient than the F-P system by $6.29 \%$ and $6.58 \%$

Psychrometric Chart

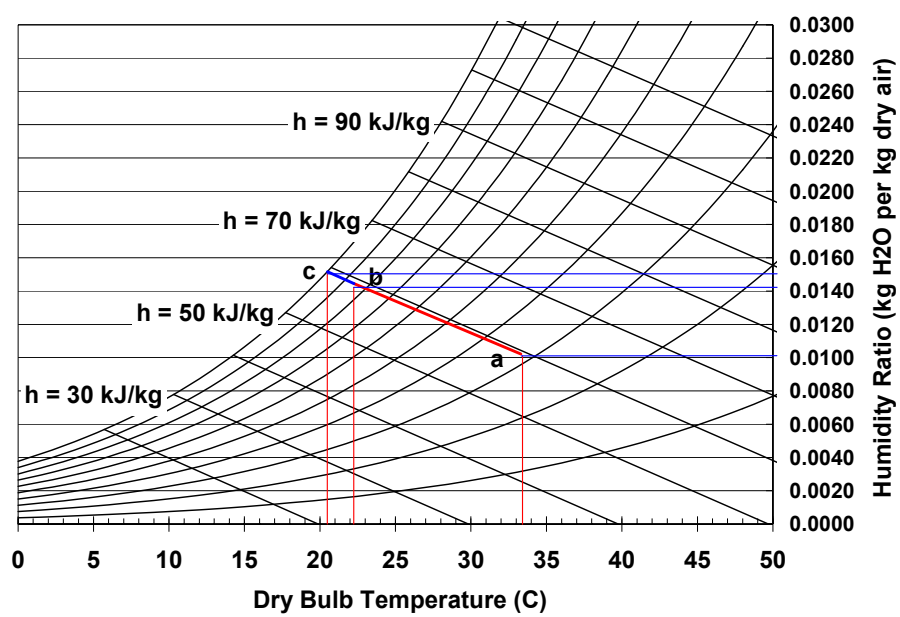

Fig. 9. The evaporative cooling process (adiabatic process) on the psychometric chart
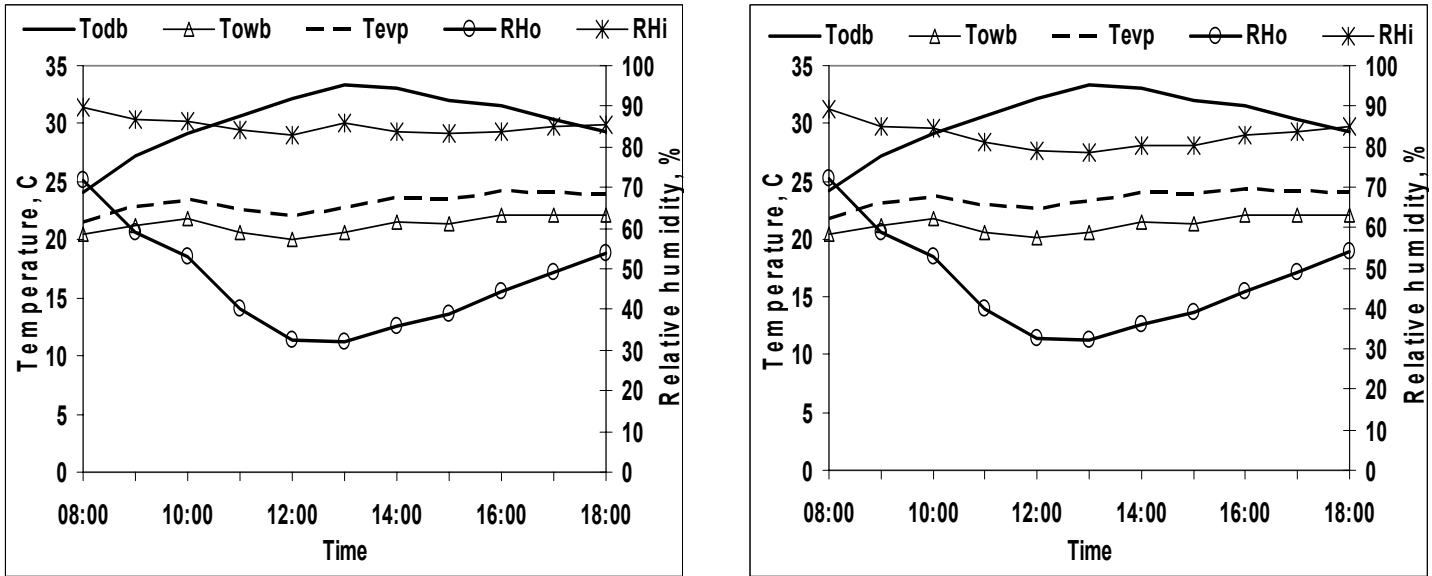

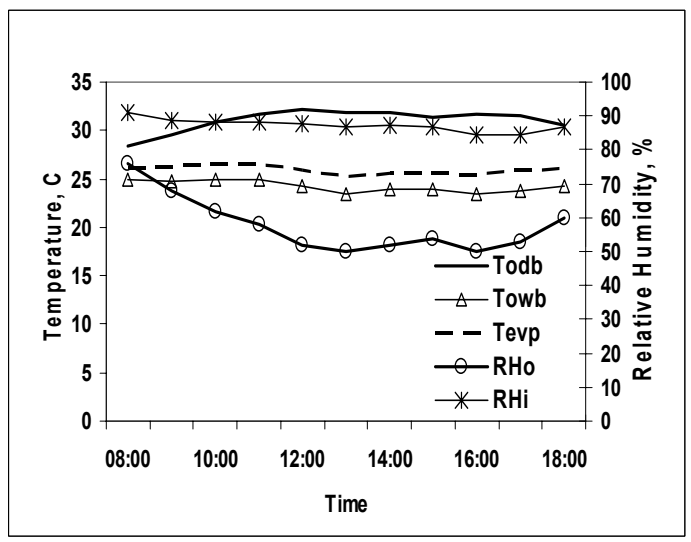

a- CU evaporative system

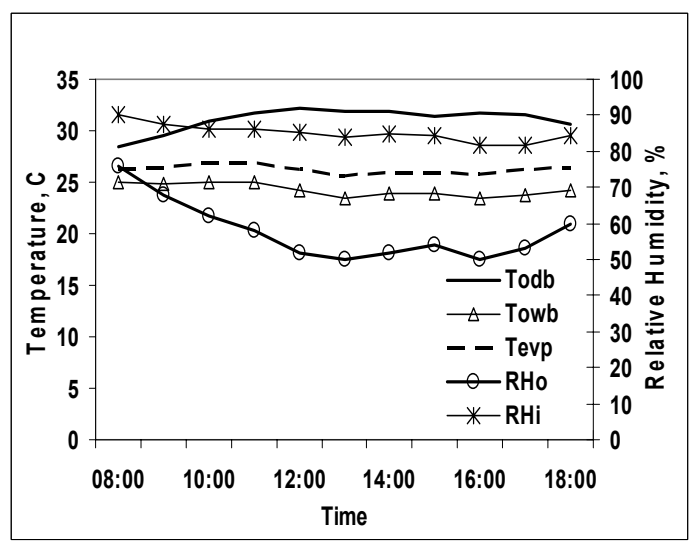

b- F-P evaporative system 
Fig. 10. Effect of dry bulb and wet bulb temperatures on the temperature of air leaving the cooling media $\left(T_{\text {evp }}\right)$ for the two cooling systems

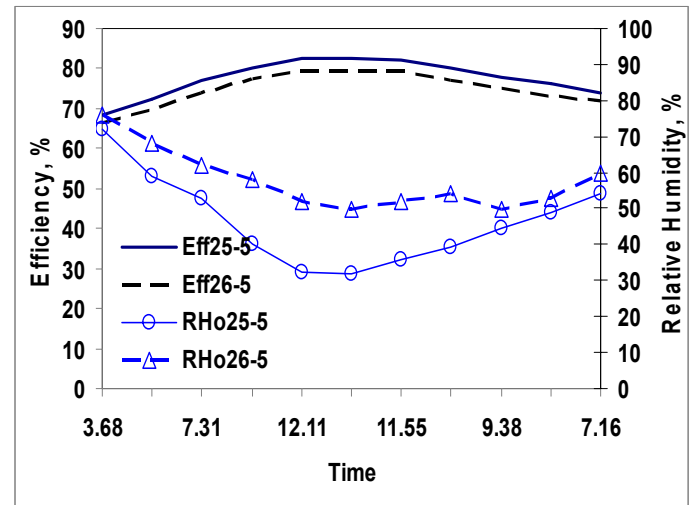

a- CU system efficiencies

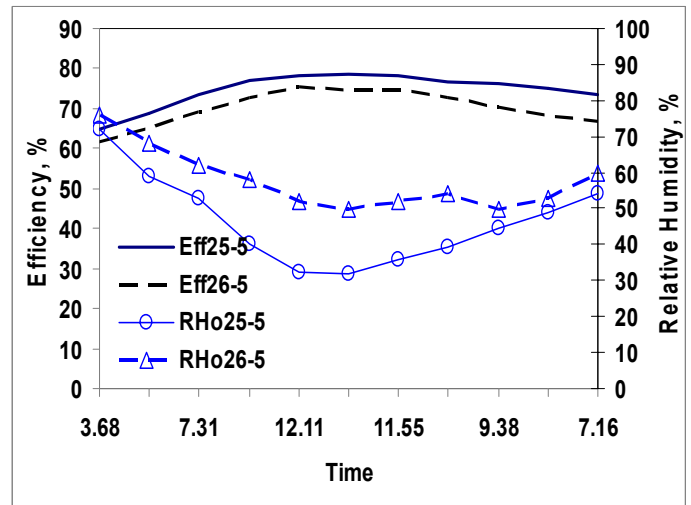

a- F-P system efficiencies

Fig. 11. The evaporative cooling efficiencies as affected by the relative humidity of outside ambient air.

The degree of cooling obtained from the two evaporative cooling systems was directly proportional to the wet-bulb depression (the difference between the dry and wet-bulb temperatures of outside air). It is imperative to predict the hourly efficiency $(\eta)$ as a function of wet-bulb depression (Td-w) for the two evaporative cooling systems. The best fit models for the two systems were illustrated in Fig. (12). The best fit models relating the efficiency $(\eta)$ to the wet-bulb depression (Td-w) were:-

$\eta(\mathrm{CU}) \%=54.3(\mathrm{Td}-\mathrm{w})^{0.167}$ with $\mathrm{R}^{2}=0.8773$

$\eta(\mathrm{F}-\mathrm{P}) \%=-0.1349(\mathrm{Td}-\mathrm{w})^{2}+3.9472 \mathrm{Td}-\mathrm{w}+50.414$ $\mathrm{R}^{2}=0.8694$

Three different water flows were tested. They were 5.6, 6.2 and $6.5 \mathrm{~L} / \mathrm{min} / \mathrm{m}$. The water flow rates of the two systems to permit optimum wetting and air saturation were 5.6 and $6.5 \mathrm{~L} / \mathrm{min}$ for the $\mathrm{CU}$ and F-P evaporative cooling systems, respectively. The percentage saving in water circulation was $16.1 \%$ for the $\mathrm{CU}$ system. The water flow rate of $\mathrm{CU}$ was below the recommended for the evaporative cooling system, (minimum $6.2 \mathrm{~L} / \mathrm{min} / \mathrm{m}$ recommended by ASABE, 2008 for the vertical corrugated cellulose pads of $100 \mathrm{~mm}$ thickness). These results may be attributed to the suction fan inside the cooling unit gripped in the water droplet to the inside the cooling unit. This saved water from falling on the ground.

The measured and calculated greenhouse air temperatures for the two systems were shown in Fig. (13). The values of error root mean square in predicting the greenhouse temperatures for both systems were 0.91 and $1.03{ }^{\circ} \mathrm{C}$ for $\mathrm{CU}$ and F-P systems, respectively. The figure indicated that the prediction model was satisfied to acquire good prediction of the greenhouse air temperature for the two systems. These were indicated by the lower values of error root mean square of both systems.

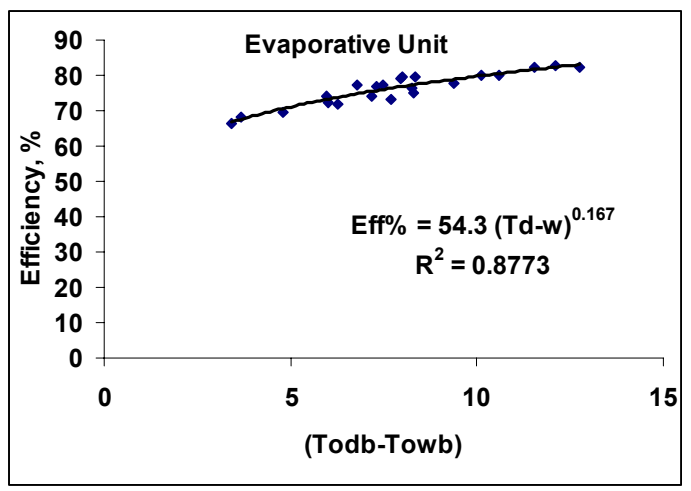

a- CU efficiency

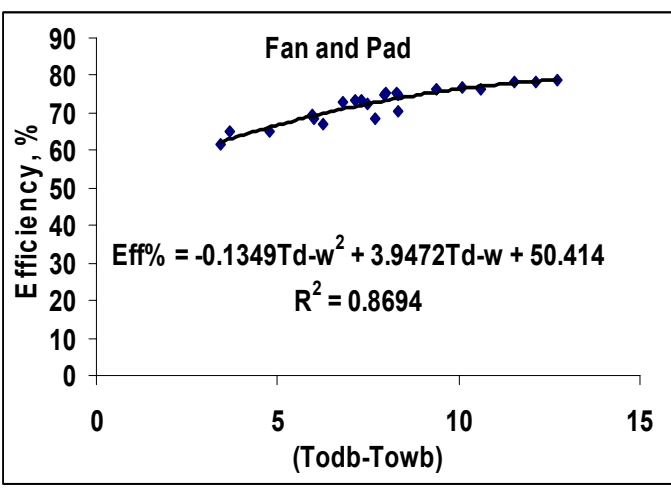

a- F-P efficiency 
Fig. 12. The evaporative cooling efficiencies as affected by the wet-bulb depression of outside ambient air

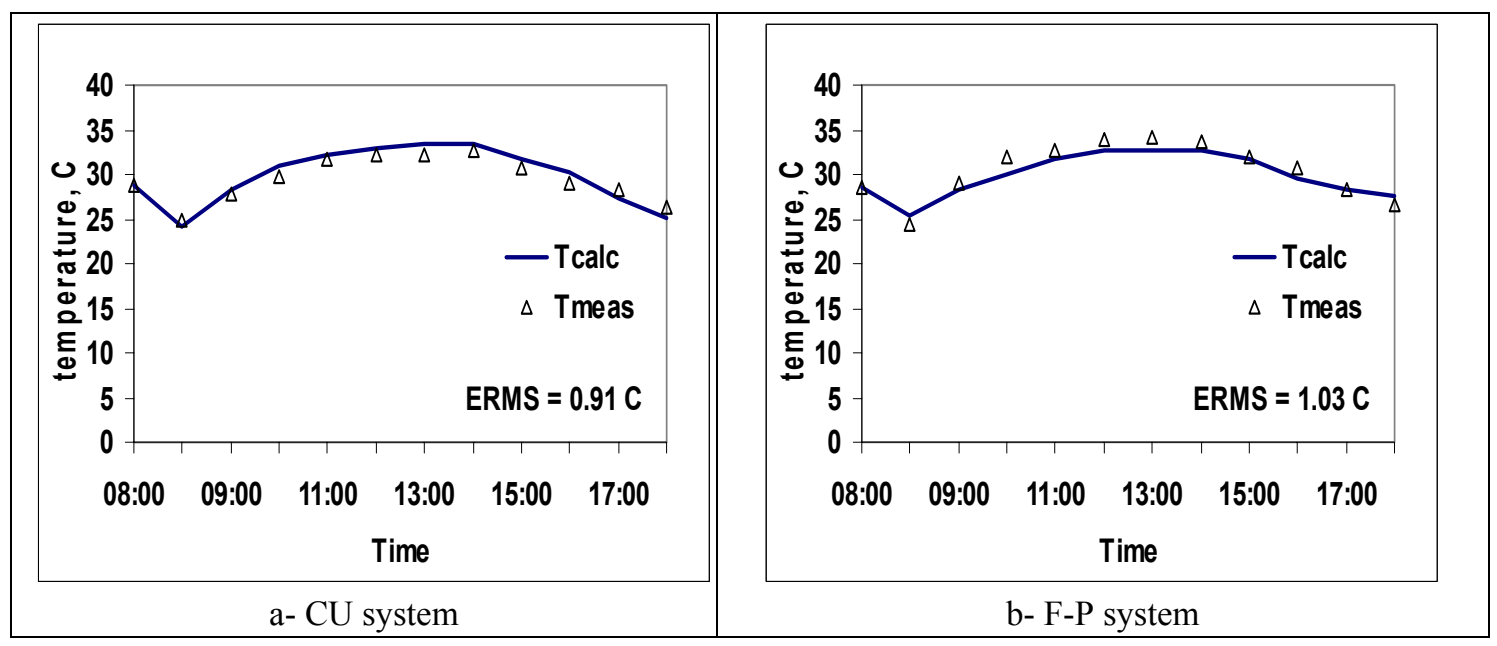

Fig. 13. Measured and calculated greenhouse air temperature for both systems.

The measured air temperatures inside greenhouses $\left(\mathrm{T}_{\text {meas }}\right)$ were plotted against the calculated air temperatures $\left(\mathrm{T}_{\text {calc }}\right)$ as shown in Fig. (14). Regression analysis revealed significant linear relationship between these parameters for the two cooling systems. The regression equations for the best fit were:-

$\mathrm{T}_{\text {meas }}(\mathrm{CU})=0.7609 \mathrm{~T}_{\text {calc }}+6.8157$ with $\mathrm{R}^{2}=$

$$
0.9648
$$

$\mathrm{T}_{\text {meas }}(\mathrm{F}-\mathrm{P})=0.7556 \mathrm{~T}_{\text {calc }}+6.8807$ with $\mathrm{R}^{2}=0.9596$

Vegetative growth and yield components of tomato plants.

Effect of the two cooling systems on the tomato productivity and fruit quality are shown in Tables (3 and 4). It is shown from table (3) that, the two cooling systems significantly affected plant length, number of branches per plant, mean fruit weight, fruit yield per plant, plant fresh weight, leaf area and dry weight. On the other hand, the two cooling systems did not significantly affected fruit length, fruit diameter and number of fruit per plant. The total yield per plant was 6.24 and $5.48 \mathrm{~kg} /$ plant for the CU and F-P systems, respectively. The CU system increased the yield of plant with $13.82 \%$ over the traditional F-P system.

The results in Table (4) indicated that the B. Carotene, lycopene and total soluble solids were significantly affected by the cooling system. Whereas, Lutein, vitamin $\mathrm{C}$, firmness, titrable acidity and dry matter percent did not significantly affected by the cooling systems.

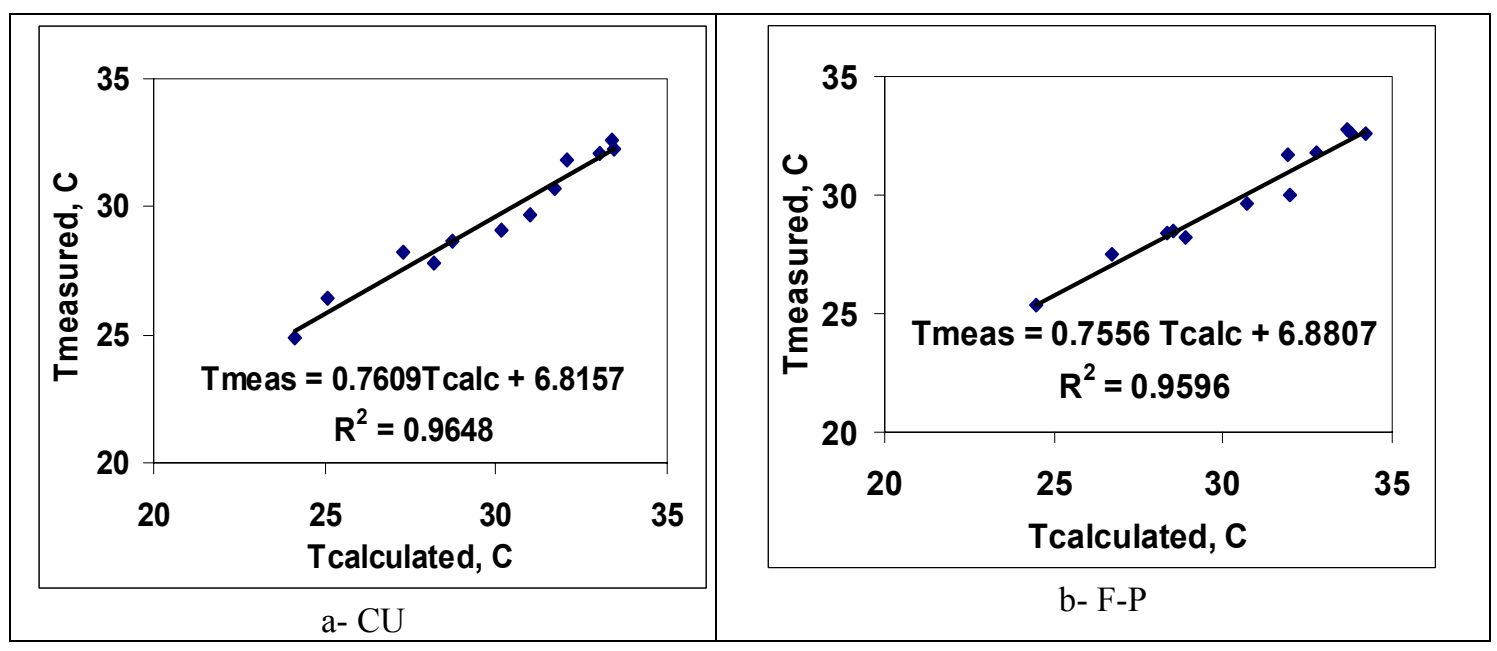


Fig. 14. Measured air temperature inside the two greenhouses versus predicted air temperature

Table 3. Vegetative growth of tomato plants in both greenhouses

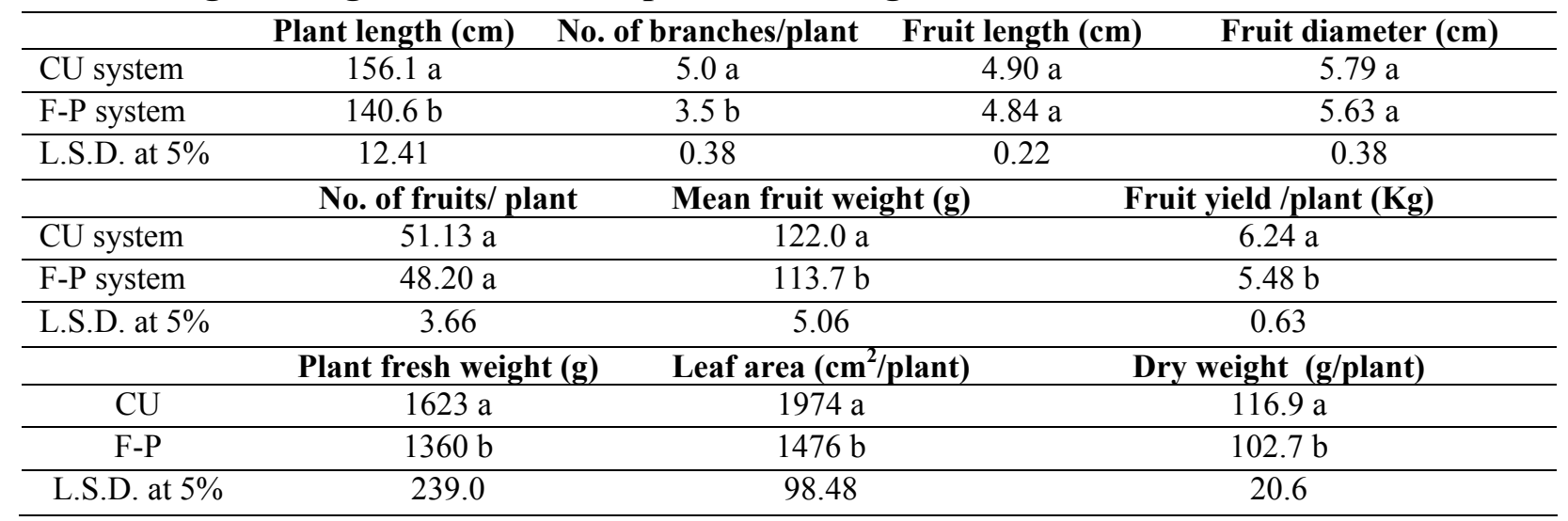

Table 4. Fruit quality of tomato in both greenhouses

\begin{tabular}{|c|c|c|c|c|c|}
\hline & B. Carotene $\left(\mathrm{mg} \mathrm{g}^{-1}\right)$ & Lycopene $\left(\mathrm{mg} \mathrm{g}^{-1}\right)$ & Lutein ( $\left.\mathrm{mg} \mathrm{g}^{-1}\right)$ & Vit.C (mg g $\left.{ }^{-1}\right)$ & T.S.S\% \\
\hline $\mathrm{CU}$ & $2.35 \mathrm{a}$ & $7.07 \mathrm{a}$ & $3.09 \mathrm{a}$ & $82.6 \mathrm{a}$ & $5.5 \mathrm{a}$ \\
\hline F-P & $1.75 \mathrm{~b}$ & $4.49 \mathrm{~b}$ & $2.87 \mathrm{a}$ & $74.0 \mathrm{a}$ & $5.4 \mathrm{~b}$ \\
\hline L.S.D. at $5 \%$ & 0.38 & 0.23 & 0.33 & 18.1 & 0.31 \\
\hline & Firmness & \multicolumn{2}{|c|}{ Titrable acidity (\%) } & \multicolumn{2}{|c|}{ Dry matter (\%) } \\
\hline $\mathrm{CU}$ & $10.93 \mathrm{a}$ & \multicolumn{2}{|c|}{$0.72 \mathrm{a}$} & \multicolumn{2}{|c|}{$5.20 \mathrm{a}$} \\
\hline F-P & $10.23 \mathrm{a}$ & \multicolumn{2}{|c|}{$0.65 \mathrm{a}$} & \multicolumn{2}{|c|}{$5.15 \mathrm{a}$} \\
\hline L.S.D. at 5\% & 1.02 & \multicolumn{2}{|c|}{0.32} & \multicolumn{2}{|c|}{0.43} \\
\hline
\end{tabular}

and relative humidity greatly affected the temperature and relative humidity level inside the two greenhouses and also, the two systems performance. According to the experimental results:-

- The temperatures of the CU greenhouse were varied from 26.9-29.0, 29.4-31.5, 32.0-34.2, 28.0-30.2 and 26.5-28.6 ${ }^{\circ} \mathrm{C}$ with an average of $27.9,30.4,33.2$, 29.1 and $27.9{ }^{\circ} \mathrm{C}$ for outside ambient temperatures of $28.7,32.4,35.4,32.1$ and $29.4{ }^{\circ} \mathrm{C}$, respectively.

- The ranges of temperature gradient inside the $\mathrm{CU}$ greenhouse were $2.1,2.1,2.2,2.2$, and $2.1{ }^{\circ} \mathrm{C}$, while, in the F-P greenhouse, these ranges were 5.9, 7.4, 8.2, 5.9 and $6.1{ }^{\circ} \mathrm{C}$ for the same ambient temperatures.

- The CU caused in higher relative humidity inside the greenhouse than the F-P.

- The average air temperature entering to greenhouse was approximately 6.82 and $7.09{ }^{\circ} \mathrm{C}$ lower than the outside air temperature for F-P and CU systems.

- The flow rate of the two systems to permit optimum wetting and air saturation were 5.6 and $6.50 \mathrm{~L} / \mathrm{min}$ for the $\mathrm{CU}$ and F-P evaporative cooling systems,
- The averages CU efficiencies were $77.55 \%$ and $74.79 \%$ in the first and second days, respectively, while they were $72.97 \%$ and $70.19 \%$ for the same days for F-P system. Consequently, the CU system was on the average more efficient than the F-P system by $6.29 \%$ and $6.58 \%$.

- The two cooling systems significantly affected plant length, number of branches per plant, mean fruit weight, plant fresh weight, leaf area and dry weight. On the other hand, the two cooling systems did not significantly affected fruit length, fruit diameter, number of fruit per plant and fruit yield per plant.

- The B. Carotene, lycopene and total soluble solids were significantly affected by the cooling system. Whereas, Lutein, vitamin C, firmness, titrable acidity and dry matter percent did not significantly affected by the cooling systems.

- The yield per plant was 6.24 and $5.48 \mathrm{~kg} /$ plant for the $\mathrm{CU}$ and F-P systems, respectively. The CU system increased the yield per plant with $13.82 \%$ over the traditional F-P system.

\section{RECOMMENDATION}


Farther research work should be done to decrease the relative humidity of ambient air to increase the evaporative cooling efficiency and to get lower comfort temperature for plant in the costal and humid areas as the relative humidity is high. The cooling unit is essential for the un-tight greenhouses as it distributes the temperature uniformly.

\section{REFERENCES}

A.O.A.C. (1990). Association of Official Agricultural Chemists. Official and Rentative Method of Analysis. Washington, D.C, U.S.A.

Abdel-Rahamn, G.M. (2006). Air temperature distribution along two greenhouses with different evaporative cooling materials. Misr J. Ag. Eng., 23(2): 463- 475.

Ahmed, E.M., O. Abaas, M. Ahmed, M.R. Ismail (2011). Performance evaluation of three different types of local evaporative cooling pads in greenhouses in Sudan. Saudi J. Biol. Sci. 18, 45-51.

Aldrich, R.A. and J.W. Bartok (1989). Greenhouse Engineering. Ed. Ithaca, New York, 14853.

ASABE Standards (2008). Heating, Ventilating and Cooling Greenhouses; ASABE standards. ANSI /ASAE EP406.4 JAN2003 (R2008). American Society of Agricultural and Biological Engineers St. Joseph, MI, USA, EP406.4:

ASHRAE (2005). Psychometrics, Ch 6: 6.1-6.17, In: American Society for Heating, Refrigeration, and Air Conditioning Engineers Fundamentals. SI ed. Atlanta

Attar, I., N. Naili, N. Khalifa, M. Hazami, M. Lazaar, and A. Farhat (2014). Experimental study of an air conditioning system to control a greenhouse microclimate. Energy Conversion and Management, 79: 543-553.

Davies, P. A. (2005). A solar cooling system for greenhouse food production in hot climates. Solar Energy, 79 (6): 661-668.

Farmahini, F.M.; S. Delfani,; J. Esmaeelian, (2012). Exergy analysis of evaporative cooling to select the optimum system in diverse climates. Energy 40, 250-257.

Franco, A., D.L. Valera and A. Pena (2014). Energy efficiency in greenhouse evaporative cooling techniques: cooling boxes versus cellulose pads Energies, 7, 14271447.

Franco, A.; D.L. Valera, A. Peña, A.M. Pérez (2011). Aerodynamic analysis and CFD simulation of several cellulose evaporative cooling pads used in Mediterranean greenhouses. Comput. Electron. Agric. 76, 218-230.

Gunhan, T.; V. Demir, A.K. Yagcioglu (2007). Evaluation of the suitability of some local materials as cooling pads. Biosyst. Eng. 96, 369-377.

Hellickson, M.L., and J.N. Walker (1983). Ventilation of Agricultural Structures. ASAE. ST. Joseph, MI. 490859659.

Helmy, M.A., M.A. Eltawil, R.R. Abo-Shieshaa, and N.M. ElZan. (2013). Enhancing the evaporative cooling performance of fan-pad system using alternative pad materials and water film over the greenhouse roof. Agric Eng Int: CIGR Journal, 15(2): 173187.

Ibrahim, M.H. (1999). Predicting microclimate conditions in greenhouses. Misr J. Agric. Eng.. 16(1): 67-82.

Ibrahim, M.H. (2010). Bio-Environmental Systems Engineering. $1^{\text {st }}$ Ed. Colors Printing Pub., Egypt. I.S.B.N.977-17-9615-1. (in Arabic).

Incropera, F.P.; and D.P. DeWitt (1999). Fundamentos de Transferencia de Calor, $4^{\text {th }}$ Ed. Prentice Hall: Upper Saddle River, NJ, USA, 1999. (in Spanish). [C. A. Franco et al., 2014m)].

Jain, D. (2007). Development and testing of two-stage evaporative cooler. Building and Environment, 42 (7): $2549-2554$

Jain, J.K.; and D.A. Hindoliya (2011). Experimental performance of new evaporative cooling pad materials. Sustain. Cities Soc. 1, 252-256.

Jamaludin, Diyana, D. Ahmad, R. Kamaruddin and H.Z.E. Jaafar (2014). Microclimate inside a Tropical Greenhouse Equipped with Evaporative Cooling Pads. Pertanika J. Sci. \& Technol. 22 (1): 255 - 271 (2014).

Katsoulas, N., D. Savas, I. Tsirogiannis, O. Merkouris, C. Kittas (2009). Response of an eggplant crop grown under Mediterranean summer conditions to greenhouse fog cooling. Sci. Hortic. 123, 90-98.

Kittas, C., T. Bartzanas, and A. Jaffrin, (2003). Temperature gradients in a partially shaded large greenhouse equipped with evaporative cooling pads. Biosystems Engineering, 85 (1): 87-94.

Kittas, C.; T. Bartzanas, and A. Jaffrin. (2001). Greenhouse evaporative cooling: measurement and data analysis. Transactions of the ASAE. 44(3): 683-689.

López, A., D.L. Valera, F.D. Molina-Aiz, and A. Peña (2012). Sonic anemometry to evaluate airflow characteristics and temperature distribution in empty Mediterranean greenhouses equipped with pad-fan and fog systems. Biosyst. Eng. 113, 334-350.

Montero, J.I. (2006). Evaporative cooling in greenhouses: Effect on microclimate, water use efficiency, and plant response. Acta Hortic. 719, 373-384.

Yakout, T.R. (2007). Some environmental control systems affecting protected cropping. Ph.D. Thesis, Mansoura University.

Youssef, G.D.M. (2007). A thermal storage system for greenhouse energy conservation. Ph.D. Thesis, Fac. of Agric., Alex. Uinv.

Sethi, V.P. and S.K. Sharma (2007a). Experimental and economic study of a greenhouse thermal control system using aquifer water. Energy Convers. Manag., 48: 306319.

Sethi, V.P. and S.K. Sharma (2007b). Survey of cooling technologies for worldwide agricultural greenhouse applications. Sol. Energy 81, 1447-1459. 



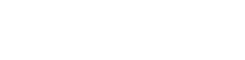

\section{تهسبن أذاء ظلم التبريد النبخيري دلل البيوت المحمية وتلثيرها عل إنتلجية الململام}

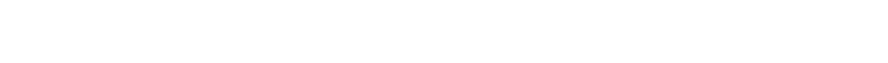

التبريد. كلن متوبط درجة حرارة الهواء الدلظل إلى

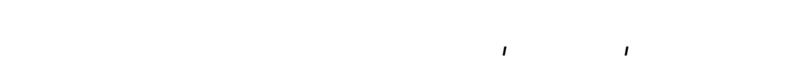
الصوبة في وحدة التبريد والوساة والمروحة على الترتيب.

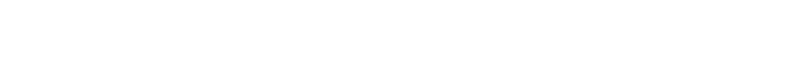

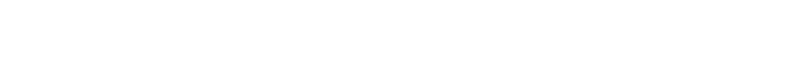

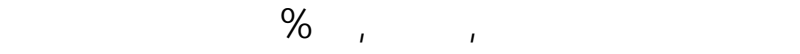

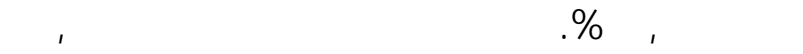

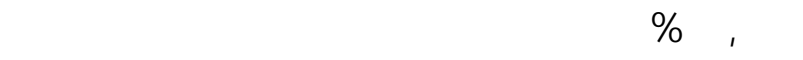

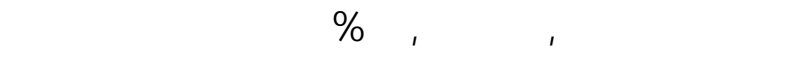
الترتيب لظلم الوسادة والمروحة. وبالتالي كلفت كفاءة وحدة التهاء

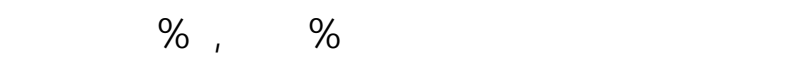
الوساة والمروحة. كان تصرف الماء الأمل الذي يدقة

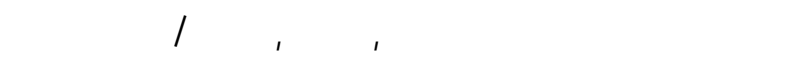

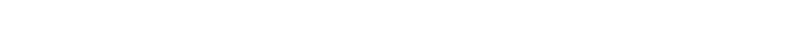

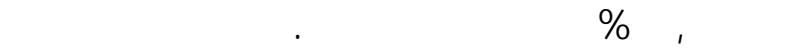

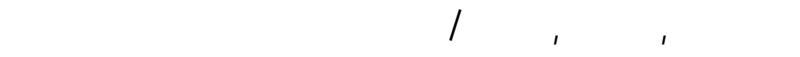

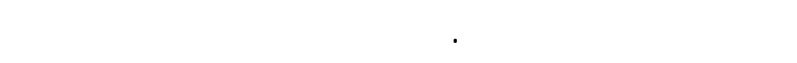

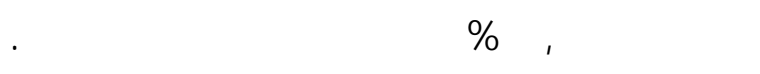

تمت هذه الدرلمة في الصوب البحثية بمططة بحوث

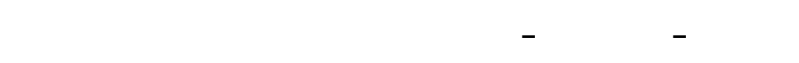

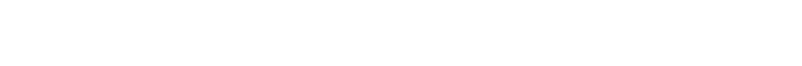

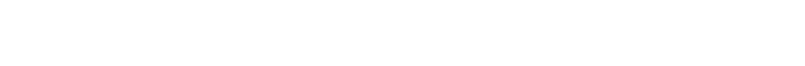
تخغيض درجة حرارة الهواء الخارجي الدلخل إلى الصوبة.

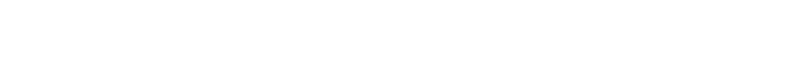
دلخل الصوبة مع ظلم تبريد المروحة والوساة. مت قيلس

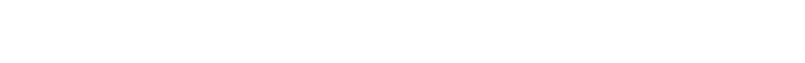

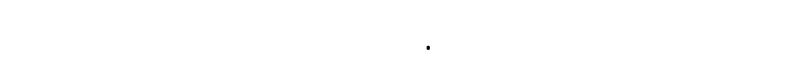
للتنبؤ بدرجة حرارة الصوبة بناء على خواص الهوباء الخاج من وسادة التبريد بكلا الظلمين. بناء على نتنائج هذه الدرلسة، عدم انظظلم درجة حرارة هواء الصوبة فى الاتجاه الطولي للصوبة. وكلات متوبط

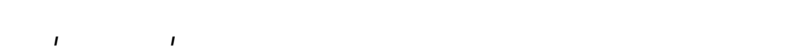

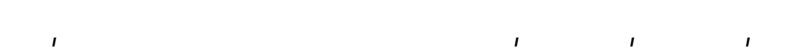

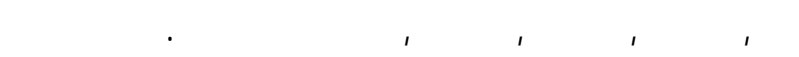

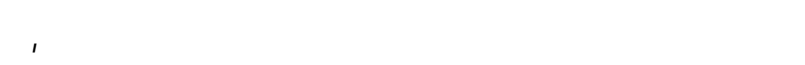

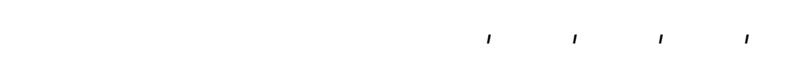

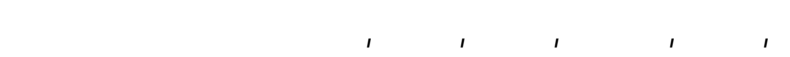


